\title{
Developing a theoretical behavioural framework and identifying its association with UK industry evidence on waste re-use
}

\author{
P. Tavri, S. Sayce \& V. Hands \\ Kingston University, UK
}

\begin{abstract}
This paper, which forms part of a larger research project, starts from the premise that there is an ambition to make the re-use of materials a normative organisational behaviour. It develops a previous literature review of barriers to organisational environmental behaviour change and presents a theoretical framework of behavioural theories, which assist in building 'associative strength' among businesses and individuals: a condition identified as critical to enabling normative behaviours to develop. It also provides an initial pilot test analysis, based on the framework of five UK organizations chosen as likely to be in the vanguard of moves towards re-use given their status as WRAP case studies and based on their own published data. In this paper, re-use refers to the management and processing of materials or items which are re-used, repurposed, repaired or redeployed thus delivering environmental, social or economic benefits to the businesses involved. A range of behavioural theories are considered and reflected within the framework, including automaticity, situational norms, identity relevance, persuasion, normative beliefs and messages, misperceptions and Corporate Social Responsibility (CSR). The proposed framework contributes by offering a systematic interpretation of different studies under a single theoretical framework. Furthermore, the pilot test analysis provides an initial interpretation of organizational behaviours and practices which might enable others to move up the waste hierarchy.

Keywords: waste re-use, normative behaviour, associative strength, communication, engagement, behavioral change maintenance, value action gap, pilot test analysis, theoretical framework.
\end{abstract}




\section{Introduction}

Figures published by the UK Environment Agency (Figure 1) show trends within waste management in England and Wales since 2000 [1]. They reveal that over the first decade of the century there has been a significant decrease in waste to landfill. However, in the last three years, since economic activity revived post recession, waste to landfill has flatlined; further by 2012 the amount of waste managed in England and Wales had risen by almost 20 percent. This rise was accompanied by 15 percent increase in consumption of resources in the same period [2]. Resources consumption underscores the need to address what happens to the materials at the end of their life. In 2012 [1], out of 167 million tonnes of waste managed in England and Wales, around 67 percent was recycled and recovered; only 2 percent went to re-use and the remainder was sent to landfill. This leads to the loss of large quantities of valuable re-usable materials and puts further pressure on a decreasing landfill capacity.

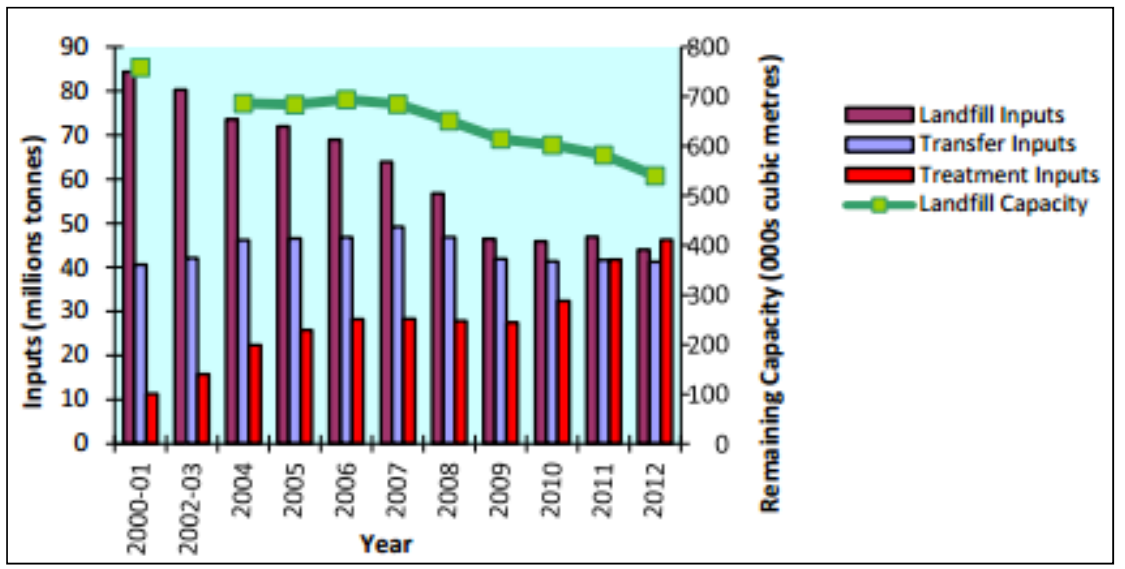

Figure 1: Waste management trend for England and Wales.

This situation is in stark contrast to the beginning of the last century when normative behaviour was re-use with landfill being the last option. One of the key points arising from the previous study by the authors [3] is that this lack of re-use is despite UK Government publishing four waste strategies (2000, 2007, 2011, 2013) all aimed at decreasing waste to landfill and promoting better resource management. The figures reveal success in moving from landfill to recycling, but not in achieving the next step up the hierarchy. Recent evidence provided by the Government's own economic analysis shows that adopting reuse activities promises to reduce landfill and the need to recycle and could be influential in reducing environmental damage and carbon emissions [4].

With the focus firmly towards moving up the waste hierarchy, this research is centred on identifying and understanding ways in which a change to re-use can take place thereby reducing the need for recycling and landfill. The authors' 
previous paper [3] identified that technological developments in the re-use sector are subject to behavioural barriers to its up-take. Consequentially, the research of which this paper forms part, seeks to understand how the application of behaviour change theories can help in filling this gap to make re-use a normative behaviour. The paper is structured in two parts:

- First: a summary of relevant, primarily environmentally related behaviour theories leading to a theoretical framework; and

- Second: the findings of the application of the framework to a pilot five organisations, which in their published reports self-profess to be in the vanguard of corporate responsibility.

\section{Developing a theoretical framework}

\subsection{Introduction}

To develop the theoretical framework literature has been taken primarily from the field of environmental behavior change. The aim is to seek and understand the reasons for re-use not currently being normative behaviour, despite the promotion of it through the UK Government's successive waste strategies since 2000. This section of paper addresses the works and types of approach that can lead to behaviour change in organisations and individuals. It has been recognized [3] that most of the literature on promoting environmental behaviour is concentrated primarily on household sector or individuals; there has been very little literature on organizational behaviour change related to the waste sector. However, it has been identified that individual and organisation behaviour are intertwined $[5,6]$ recognizing that organizations are made up of people.

One particular organizational characteristic that was revealed as relevant and effective in enabling change is that of developing 'associative strength' [7]. Within the literature a number of studies identified theories that help in building associative strength. These are: communication, engagement/action, behavioural maintenance and the avoidance of a 'value action gap'. However, it was noted that none of the literature relates specifically to waste re-use, making the current study unique within the field of enquiry.

\subsubsection{Communication theories}

Behaviour studies covering the following: sustainable ethical behaviour within firms [5], misperception of social norms [8], misperception or boomerang effect of marketing campaigns [9] and normative beliefs and conservation behaviours [10] all indicate that communication is an important factor in developing associative strength within a group or an organisation. In particular a study by Kelman [11] identified four types of communication that determine conditions for changes in attitude. One of them, "low means control" has been discarded from the study because of research limitations. The relevant three high level communications are:

- "High means control" means applying mandatory rules and regulations. In illustration of this, a study of corporate behaviour [12] emphasises governance systems, regulations, enforcement and environmental policy as 
the means to influence corporate behaviour, especially when firms know that non-compliance decisions can affect a firm's ability to operate.

- "High attractiveness" means the influence of peer or external pressures. Stern [13], in developing a framework for promoting pro-environmental behaviour, identified external forces as an important factor in leading to behaviour change. Further, an empirical study of the corporate behaviour of 14 pulp and paper manufacturers [14] concluded that fear of action by environmental groups led to behaviour change.

- "High credibility" means the embedding of research based on facts and knowledge. It particularly relates to a study by Cialdini [15] on providing descriptive normative messages for influencing behaviour towards protecting the environment.

All three mechanisms are high level and all three are important in terms of building associative strength. Relating this to the current study, the Government has been communicating importance of re-use through high level means i.e., waste strategies, legislations and regulations. However, by themselves high level means have not proved sufficient to be effective - there is also a need to engage to promote action towards embedding re-use as normal behaviour.

\subsubsection{Engagement/action theories}

Converting communication into action requires acting on accepted shared goals. When a goal is agreed, habitual plans or actions to achieve that goal are automatically activated [6, 16, 17]. Lachman et al. [18], in their study on a theoretical framework for cross cultural analysis, argued that resources and technology availability can have an important impact on organisations' ability to adapt to pressures; this may affect approaches towards re-use which might well involve changes in resourcing, process and technology adoption. However, building associative strength for activating goals not only depends on the quantifiable variables such as resources and technology, but is also influenced by several qualitative variables.

A study by Bargh and Ferguson [17] on automatic behaviour showed that to achieve a common goal within an organisation, employees tend to establish a rapport or friendship by mimicking others. In addition, Cialdini et al.'s study on substantial norms' affect on human behaviour [19] and Kallgren et al.'s study on factors altering the relationship between norms and behaviours [16] both identify the "focus of attention" as an important variable that creates an appropriate environment for achieving the desired goal. The right environment or situation automatically elicits the behaviour by activating the goal [20]. A further study [21] on sustainable business practice argues that contextual, personal and sector environment all play important roles in influencing behaviour to achieve a common goal. In support, Stern [13] and Nye and Hargreaves [22], both identify contextual factors as important variables in developing associative strength. Therefore, the social context needs to be understood and accounted for in behavioural interventions. Furthermore, for that reason it is likely that adopting re-use practices in organizations where environmental awareness is valued provides an appropriate context. 
Engagement/action theories go further; in addition to social context and resource availability to enable the building of associative strength to enable goal delivery, it is argued that there needs to be a link between goal and action to create a habit or norm. A study on automatic behaviour [23] illustrates that habit is the link between goal and action that is instrumental in attainment. Relating this to the history of waste: re-use used to be a habitual behaviour, primarily for economic imperatives. However, with increased wealth and the rise of a consumption norm, the habit of re-use has fallen away. For the government to succeed in achieving their waste strategy, a realignment of habitual behaviour away from landfill and re-cycling to re-use is required. However, it is indicated [11] that adopting new behaviour and embedding it is as a habit incurs costs, so there need to be recognized benefits to compensate. UK Government [4] has evidence which proves re-use activities are more economically and environmentally beneficial than recycling, recovery or landfill. But this has to be known and accepted before action will ensure. However, developing a habit is one thing; maintaining and monitoring it is another. The evaluation of the newly acquired habit (or in the case of re-use re-acquired behaviour) depends on an effective monitoring process; this is now considered.

\subsubsection{Behavioural maintenance}

Measuring and monitoring is crucial to ensure that the changed behaviour is maintained, even if it has become habitual. Behavioural maintenance depends on perceived satisfaction with resultant outcomes based on the acquired behaviours [11]. Rothman [24, p. 65] in his study of maintenance of new behaviours concluded that "given the repeated application of intervention strategies that facilitate short term success does little to improve rates of long term success, the premise that there are important differences in the psychological processes that govern behavioural initiation and maintenance appears worthy of consideration". In his study, Rothman proposed an alternative framework which provides a difference between the change in behaviour and its maintenance. This implied that long-term change will not happen without monitoring and maintaining the changed behaviour. Part of this maintenance is stakeholder communication to ensure continued associative strength; without it a so-called 'value action gap' may emerge. The following section will provide a summary on 'value action gap' and the importance to support of re-use should it be successfully introduced.

\subsubsection{Avoidance of 'value action gap'}

The 'value action gap' has been defined in a study on pro-environmental behaviour [25] as the difference in beliefs and actual behaviours. A study by Kollmuss and Agyeman [26], in recognising its importance, concluded that it is a common cause of failure in pro-environmental behaviour models. The implication is that many models fail to take into account individual, social, cultural and economic constraints and assume humans are rational beings who make systematic use of information provided, whereas, in reality, this may not be the case. Based on these findings it is evident that understanding individual, social, cultural and economic circumstances is crucial to the avoidance of a 
'value action gap'. Furthermore, communication, information and engagement all play important roles in avoidance of any 'value action gap', which associates directly with communication and engagement theories. It is not enough to simply gain belief in changes - such as to re-use - those implementing the action will requires support and reinforcement of the behaviour.

\subsection{Conclusion}

In conclusion, the analysis of behaviour theories, all of which have a track record within environmentally focused literature, indicates that the factors building associative strength to change behaviour and maintain it are interconnected and dependent on one another. From these a schematic framework (Figure 2) has been developed to offer an interpretation of the various studies which previously have not been considered together under a single theoretical framework. Part A of the theoretical framework shows an association within identified factors that is, communication, engagement/action, behavioural maintenance and avoidance of 'value action gap'.

To tentatively test the framework put forward in Figure 2, the following section provides an initial consideration and analysis of a pilot of five companies chosen as ones likely to provide evidence of progress towards re-use.

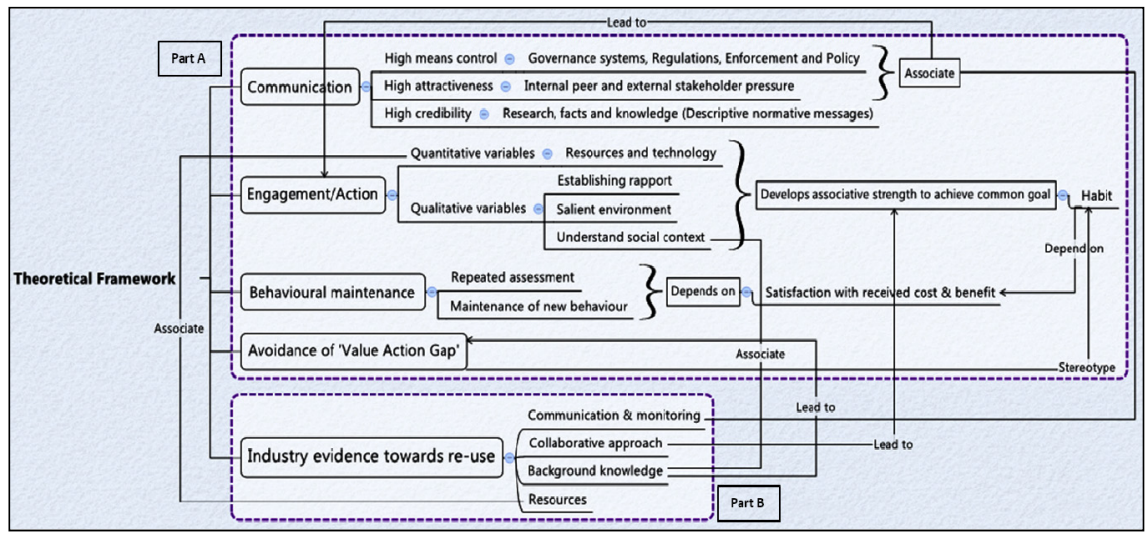

Figure 2: Theoretical framework.

\section{Associating developed framework with industry evidence of progress towards re-use}

\subsection{Introduction}

The following section presents a small scale initial pilot test of the behaviours towards re-use of five companies by putting quantitative measures on their policies and actions based on the framework in Figure 2 and using only evidence from their stated own objectives and actions. All five companies are UK based and have signed up to compliance with the Global Reporting Initiative (GRI); 
further they are all companies that have been selected from those who are on a list of WRAP (www.wrap.org.uk) case studies in waste best practice conducted in 2012 and 2013.

The companies selected are from different sectors but whilst all could be regarded as towards the lead in terms of waste management, one is a selfproclaimed vanguard organisation and is a mixed retailer; the remaining four comprise a mixed retailer, a food retailer, a construction company and a charity. The textual information gathered was taken from published reports including: sustainability reports, corporate responsibility and sustainability reports, CSR report and trustees' reports. The published reports themselves are part of their internal and external facing communication plans. For the reports, the companies' own evidence base was analysed against the characteristics of the identified behaviour theories. Furthermore, the analysis was designed to give an insight as to whether the companies are undertaking similar actions in relation to re-use or moving along different paths up the waste hierarchy. Last, the purpose was to provide information as to whether such publicly available information forms a suitable basis for testing the validity of the framework and its suitability for wider application to other companies.

\subsection{Initial pilot test analysis}

Table 1 sets out the criteria taken from the theoretical framework and against which the pilot companies' objectives, policies and achievements were considered and quantified. These factors are extensively elaborated in the appendix. The measurement is based on a simple three-point likert scale with 3 being 'strong' evidence, 2 being 'some' evidence and 1 being 'only weak if any' evidence of association with the criterion.

Table 1.

\begin{tabular}{|c|c|c|c|c|}
\hline \multicolumn{2}{|r|}{ Likert scale } & \multirow[b]{2}{*}{3} & \multirow{2}{*}{2} & \multirow[b]{2}{*}{1} \\
\hline Criteria & Factors & & & \\
\hline $\begin{array}{l}\text { Communication: High Means } \\
\text { Control }\end{array}$ & Waste Hierarchy & & & \\
\hline \multirow{2}{*}{$\begin{array}{l}\text { Communication: High } \\
\text { Attractiveness }\end{array}$} & $\begin{array}{l}\text { Internal and external feedback for changes in } \\
\text { system }\end{array}$ & & & \\
\hline & Comparative analysis with competitors & & & \\
\hline \multirow{3}{*}{$\begin{array}{l}\text { Communication: High } \\
\text { Credibility }\end{array}$} & Guidelines & & & \\
\hline & Innovation & & & \\
\hline & $\begin{array}{l}\text { Achievements \& improvements from previous } \\
\text { year }\end{array}$ & & & \\
\hline & Likert scale & \multirow{2}{*}{3} & \multirow{2}{*}{2} & \\
\hline Criteria & Factors & & & 1 \\
\hline \multirow{2}{*}{ Engagement/ Action } & Long term/ strong relationship & & & \\
\hline & Quantitative and qualitative benefits & & & \\
\hline \multirow{2}{*}{ Behavioural Maintenance } & Pre-assessment on suppliers & & & \\
\hline & Regular monitoring & & & \\
\hline \multirow{3}{*}{$\begin{array}{l}\text { Avoidance of 'Value Action } \\
\text { Gap' }\end{array}$} & Diverse group both internal and external & & & \\
\hline & $\mathrm{HMC} / \mathrm{HC}$ & & & \\
\hline & Engagement / Action & & & \\
\hline
\end{tabular}


On the basis of Table 1, Table 2 provides an overall ranking of the companies' approach to waste re-use as revealed through their public documentation. The final analysis showed the mixed retailer achieving the highest score of the five whereas the self-claimed vanguard company ranked the lowest.

Table 2.

\begin{tabular}{|l|l|l|l|l|l|l|}
\hline Criteria & \multicolumn{3}{|l|}{ Communication } & Engagement/ & Behavioural & $\begin{array}{l}\text { Avoidance of } \\
\text { Maintenance } \\
\text { Value Action } \\
\text { Gap' }\end{array}$ \\
\hline $\begin{array}{l}\text { Company } \\
\text { type }\end{array}$ & HMC & HA & HC & Action & 3 & 3 \\
\hline $\begin{array}{l}\text { Mixed } \\
\text { retailer }\end{array}$ & 3 & 2 & 3 & 3 & 3 & 2 \\
\hline Food retailer & 3 & 3 & 2 & 3 & 2 & 2 \\
\hline Construction & 3 & 2 & 2 & 2 & 2 & 2 \\
\hline $\begin{array}{l}\text { Self-claimed } \\
\text { vanguard }\end{array}$ & 3 & 1 & 3 & 1 & 1 & 2 \\
\hline Charity & 3 & 2 & 2 & 2 & 3 & \\
\hline
\end{tabular}

Considering that these all are chosen from the WRAP case studies, it is not surprising that all companies ranked 3 on High Means Control (HMC); however none scored a 3 on High Attractiveness (HA). From the reports there was a lack of information on any benchmarking or comparative competitor analysis, so there was no direct evidence of responses to external peer or other pressures. Apart from HMC the only area in which every company scored at least 2 was 'value action gap' avoidance. For this differing actions were noted. For instance, along with diverse employment opportunities the mixed retailer also provides employee ownership but it was the only one so to do; whereas the selfproclaimed vanguard mixed retailer is undertaking re-use involving community and employees. The food retailer evidenced value action association through gaining a gold accreditation for being one of the top companies in terms of investing in staff. Finally, the construction company and the charity both operate training and volunteering opportunities aimed at benefitting staff, though these do not relate directly to re-use schemes. In terms of engagement/action and behavioural maintenance, the highest ranked were the mixed and food retailers because of their work towards establishing long term sustainable partnerships for both qualitative and quantitative benefits. In relation to behavioural maintenance, analysis of the actions and monitoring mechanisms revealed that two companies are undertaking structured activity by considering pre-assessment process as an important element and were given a score of 3 , whereas action by the other companies was noted as informal.

Through the analysis it was identified that significant progress is being made by all these companies towards re-use; however recycling is still their normative behaviour. Some of the objectives and strategies considered by businesses towards waste management are directly associated with behaviour theories that build associative strength but more and deeper analysis is required to fully 
understand their positions. The analysis provides evidence that the range of actions and their formal embedding differs from organisation to organisation suggesting the existence of areas of complementary strengths which could potentially provide opportunities for collaborative organisational learning.

The above presents a very tentative analysis as it is based only on a short series of published documents that, although they fit within a GRI framework, all choose to report on different activities; further companies may have underreported. Nonetheless, although it would be unwise to draw any firm conclusions from the analysis, it does indicate that the framework provides a methodology capable of refinement and application to a wider sample thereby yielding more detailed information which could provide a base line for sharing of information between companies and the emergence of re-use good practice examples. What it also shows is that all five are to greater or lesser extents and in differing ways seeking to implement policies which provide evidence of the pursuit of associative strength.

\section{Further research}

Seeking to apply the framework to real life re-use practice, it was found possible to draw out evidence sufficient to provide a tentative initial ranking. It also provides evidence that transformation is happening at the leading organization level where there is a proven motivation to move up the waste hierarchy. However, the bigger challenge is to convert this transformative action into sustained normative behaviour. Although the evidence points to improvements in waste management being firmly embed in governance and policies in every case, variation in quantitative measures adopted indicate that they are taking different routes and setting different priorities. In part this may be due to the diverse nature of the sectors in which they operate and their historical positioning, but with this sample size it is too small to tell. To validate the findings further work needs to be done. The next steps will be conduct selected case studies whilst simultaneously extend the document analysis to a much wider range of companies, including those not likely to be in the vanguard of change and to extend the analysis to a full content methodology. Results from the case studies will then be triangulated back to the developed framework in order to refine the framework for wider application. 


\section{Appendix}

\begin{tabular}{|c|c|c|c|c|}
\hline Criteria & & Engagement/ & & \\
\hline $\begin{array}{l}\text { Company } \\
\text { Type }\end{array}$ & $\begin{array}{c}\text { Communication: HMC, } \\
\text { HA, HC }\end{array}$ & $\begin{array}{c}\text { Action: } \\
\text { Quantitative, } \\
\text { Qualitative, } \\
\text { Both }\end{array}$ & $\begin{array}{c}\text { Behavioural } \\
\text { Maintenanc } \\
\text { e }\end{array}$ & $\begin{array}{c}\text { Avoidance of } \\
\text { 'Value Action } \\
\text { Gap' }\end{array}$ \\
\hline $\begin{array}{l}\text { Mixed } \\
\text { retailer }\end{array}$ & $\begin{array}{l}\text { - Reduce, re-use, recycle } \\
\text { and recovery as a waste } \\
\text { hierarchy. (HMC) } \\
\text { - Segregation of waste at } \\
\text { source. (HMC) } \\
\text { - Collective work through } \\
\text { online survey to } \\
\text { changing needs. (HA) } \\
\text { - Sharing information } \\
\text { through best practice } \\
\text { guidelines. (HC) } \\
\text { - Diverted 92.1\% waste } \\
\text { going to landfill. (HC) } \\
\text { At Liverpool 192 sofas } \\
\text { for re-use and recycle, of } \\
\text { which } 65 \% \text { sofas re- } \\
\text { used. (HC) } \\
\text { Introduced new ways of } \\
\text { re-use packaging. (HC) }\end{array}$ & $\begin{array}{l}\text { - Less wasteful, } \\
\text { incorporated } \\
\text { stock control } \\
\text { management. } \\
\text { - Strong } \\
\text { relationship } \\
\text { with internal } \\
\text { and external } \\
\text { stakeholders. } \\
\text { Food feed to } \\
\text { the people in } \\
\text { collaboration } \\
\text { with a food } \\
\text { retailer. } \\
\text { Partnership } \\
\text { ensures that } \\
\text { people work } \\
\text { together } \\
\text { effectively. } \\
\text { Win-win } \\
\text { approach with } \\
\text { FRN. } \\
\text { Work closely } \\
\text { with local } \\
\text { suppliers. }\end{array}$ & \begin{tabular}{|l} 
Exploring \\
innovative \\
ways of \\
treating \\
waste. \\
- Sites are risk \\
assessed on \\
regular basis \\
Pre- \\
assessment \\
of new \\
suppliers.
\end{tabular} & $\begin{array}{l}\text { - Diverse } \\
\text { employment } \\
\text { market and } \\
\text { multi- } \\
\text { generational } \\
\text { workforce and } \\
\text { supporting } \\
\text { priority groups. } \\
\text { - Employee } \\
\text { ownership, key } \\
\text { to the } \\
\text { partnership } \\
\text { success. }\end{array}$ \\
\hline $\begin{array}{l}\text { Food } \\
\text { retailer }\end{array}$ & $\begin{array}{l}\text { - Zero landfill food waste } \\
\text { policy. (HMC) } \\
\text { - Have climate change } \\
\text { strategy at operations, } \\
\text { product and customers } \\
\text { level. (HMC) } \\
\text { - Compare to competitors } \\
\text { and regularly take } \\
\text { external perspective on } \\
\text { performance. (HA) } \\
\text { - Over 9m items of } \\
\text { clothing and } 1.7 \mathrm{~m} \text { books } \\
\text { donated. (HC) } \\
\text { Over 2m meals donated } \\
\text { UK's largest food drive. } \\
\text { (HC) } \\
\text { Donate food fit for } \\
\text { consumption to charities } \\
\text { such as Fare Share and } \\
\text { Food Cycle and send } \\
\text { bakery waste for animal } \\
\text { bedding. (HC) }\end{array}$ & $\begin{array}{l}\text { - Critical values } \\
\text { to be most } \\
\text { trusted retailer, } \\
\text { where people } \\
\text { love to work } \\
\text { and shop. } \\
\text { - Long term } \\
\text { sustainable } \\
\text { partnership } \\
\text { with suppliers. }\end{array}$ & $\begin{array}{l}\text { Have } \\
\text { monitoring } \\
\text { and tracking } \\
\text { performance } \\
\text { measures in } \\
\text { place. }\end{array}$ & $\begin{array}{l}\text { - Encourage } \\
\text { disadvantage } \\
\text { groups, awarded } \\
\text { gold } \\
\text { accreditation for } \\
\text { investing in staff } \\
\text { for business } \\
\text { improvement }\end{array}$ \\
\hline
\end{tabular}




\begin{tabular}{|c|c|c|c|c|}
\hline \multirow{2}{*}{$\begin{array}{l}\text { Criteria } \\
\text { Company } \\
\text { Type }\end{array}$} & \multirow[b]{2}{*}{$\begin{array}{c}\text { Communication: HMC, } \\
\text { HA, HC }\end{array}$} & \multirow{2}{*}{$\begin{array}{c}\text { Engagement/ } \\
\text { Action: } \\
\text { Quantitative, } \\
\text { Qualitative, } \\
\text { Both } \\
\end{array}$} & \multirow{2}{*}{$\begin{array}{l}\text { Behavioural } \\
\text { Maintenanc } \\
\text { e }\end{array}$} & \multirow{2}{*}{$\begin{array}{c}\text { Avoidance of } \\
\text { 'Value Action } \\
\text { Gap' }\end{array}$} \\
\hline & & & & \\
\hline Construction & $\begin{array}{l}\text { - Follow UK waste } \\
\text { hierarchy site by site to } \\
\text { reduce waste. (HMC) } \\
\text { - Engage with employees } \\
\text { through roadshows and } \\
\text { feedbacks, costumers } \\
\text { through satisfaction } \\
\text { surveys and community } \\
\text { through Considerate } \\
\text { Constructors Scheme. } \\
\text { (HA) } \\
\text { - Commitment to share best } \\
\text { waste practice extends to } \\
\text { suppliers and } \\
\text { subcontractors. (HC) } \\
\text { In } 2012-13 \text { reused: } 39.4 \%, \\
\text { recycled and recovered: } \\
31.2 \% \text {, disposal went up } \\
\text { by } 2.4 \% \text {. (HC) } \\
\text { In } 12 \text { months } 477 \mathrm{~T} \text { waste } \\
\text { wood either re-used or } \\
\text { recycled. (HC) }\end{array}$ & \begin{tabular}{|l|} 
- Collaborative \\
bid success, \\
obtained funding \\
from Business, \\
Innovation and \\
Skills. \\
- Donated around \\
185,486 man- \\
hours for \\
community \\
work and raised \\
fund of around \\
$£ 113,028$ for \\
charity partner. \\
Partnership \\
agreement with \\
National \\
Community \\
Wood Recycling \\
Project, \\
signatory to the \\
WRAP half \\
waste recycling.
\end{tabular} & $\begin{array}{l}\text { Effective risk } \\
\text { management } \\
\text { Independent } \\
\text { assessment of } \\
\text { management } \\
\text { system. }\end{array}$ & $\begin{array}{l}\text { - Offer training and } \\
\text { volunteering } \\
\text { opportunities to } \\
\text { increase } \\
\text { employment for } \\
\text { diverse workforce. }\end{array}$ \\
\hline $\begin{array}{l}\text { Self- } \\
\text { claimed } \\
\text { vanguard }\end{array}$ & $\begin{array}{l}\text { - Zero Waste to landfill. } \\
\text { (HMC) } \\
\text { - Shopping raised } £ 2.3 \mathrm{~m} \text { for } \\
\text { a charity this year and } \\
\text { reused or recycled around } \\
3.8 \mathrm{~m} \text { shopped items. (HC) } \\
\text { - Fresher for Longer } \\
\text { initiative, practical advice } \\
\text { for customers for usage of } \\
\text { store and food properly. } \\
\text { (HC) } \\
\text { - } 28 \% \text { reduction in overall } \\
\text { waste production and } 32 \% \\
\text { reduction in food waste } \\
\text { since 2008/09. (HC) }\end{array}$ & $\begin{array}{l}\text { Partnership with } \\
\text { suppliers and } \\
\text { retailers part of } \\
\text { Courtauld } \\
\text { commitment. }\end{array}$ & & $\begin{array}{l}\text { Extending garment } \\
\text { re-use/exchange } \\
\text { scheme at work to } \\
\text { make it easier for } \\
\text { community } \\
\text { involvement. }\end{array}$ \\
\hline Charity & $\begin{array}{l}\text { Follow principles of 4Rs } \\
\text { (reduce, re-use, repair } \\
\text { and recycle). (HMC) } \\
\text { - Community involvement } \\
\text { and raising waste } \\
\text { reduction awareness. } \\
\text { (HA) } \\
\text { - New Look Shop } \\
\text { approach, a way of } \\
\text { marketing. (HC) } \\
\text { Over a year more than } \\
3.8 \mathrm{~m} \text { items were } \\
\text { shopped raising } £ 2.3 \mathrm{~m} . \\
\text { (HC) }\end{array}$ & $\begin{array}{l}\text { - Strengthen } \\
\text { donor } \\
\text { relationship. } \\
\text { - Strengthen } \\
\text { relationship in } \\
\text { home and } \\
\text { abroad. } \\
\text { Collaboration } \\
\text { with one of the } \\
\text { food retailers } \\
\text { where they } \\
\text { have } 460 \\
\text { banks in } 300 \\
\text { premises. }\end{array}$ & $\begin{array}{l}\text { Built } \\
\text { partnership } \\
\text { through pre- } \\
\text { assessment } \\
\text { process. } \\
\text { Internal } \\
\text { control and } \\
\text { risk } \\
\text { management } \\
\text { system in } \\
\text { place for } \\
\text { measuring } \\
\text { performance } \\
\text {. }\end{array}$ & $\begin{array}{l}\text { - Humanitarian } \\
\text { and strategic } \\
\text { aims based on } \\
\text { fundamental } \\
\text { human rights. } \\
\text { - Equal } \\
\text { opportunities } \\
\text { policy, training, } \\
\text { targets and } \\
\text { practical actions. }\end{array}$ \\
\hline
\end{tabular}




\section{References}

[1] Waste data and information; UK, Environment Agency, Online. http://www.environment-agency.gov.uk/research/library/data/34169.aspx

[2] Office for National Statistics, Updated estimates of UK Resource Use using Raw Material Equivalents, UK, 2013.

[3] Tavri, P., Sayce, S., \& Hands, V., Waste Re-use and Preparing for Re-use: The top priority. Proc. of the $2^{\text {nd }}$ International Conference and Exhibition WASTES: Solutions, Treatments and Opportunities, eds. F. Castro, C. Vilarinho, J. Carvalho, A. Castro, J. Araujo, \& A. Pedro., CVR: Portugal, pp. 465-470, 2013.

[4] Waste Prevention Programme for England Call for evidence; UK Department for Environment, Food and Rural Affairs (DEFRA), Online. https://www.gov.uk/government/consultations/call-for-evidence-wasteprevention-programme-for-england.

[5] Thomas, T., Schermerhorn, Jr. J.R. \& Dienhart, J.W., Strategic leadership of ehtical behaviour in business. Academy of Management Executive, 18(2), pp. 56-66, 2004.

[6] Campbell, J.L., Why would corporations behave in socially responsible ways? An institutional theory of corporate social responsibility. Academy of Management Review, 32(3), pp. 946-967, 2007.

[7] Collier, J. \& Esteban, R., Corporate social responsibility and employee commitment. Business Ethics: A European Review, 16(1), pp. 19-33, 2007.

[8] Wenzel, M., Misperceptions of social norms about tax compliance: From theory of intervention. Journal of Economic Psychology, 26, pp. 862-883, 2005.

[9] Schultz, P.W., Nolan, J.M., Cialdini, R.B., Goldstein, N.J. \& Griskevicius. V., The constructive, Destructive, and Reconstructive powers of Social Norms. Association for Psychological Science, 18, pp. 429-434, 2007.

[10] Gockeritz, S., Schultz, P.W., Rendon, T., Cialdini, R.B., Goldstein, N.J. \& Griskevicius, V., Descriptive normative beliefs and conservation behaviour: The moderating roles of personal involvement and injunctive normative beliefs. European Journal of Social Psychology. 40, pp. 514-523, 2010.

[11] Kelman, H.C., Compliance, Identification, and Internalization: Three Process of Attitude Change. The Journal of Conflict Resolution, 2(1), pp. 51-60, 1958.

[12] Cashore, B. \& Vestinsky. I., Policy network and firm behaviours: Governance systems and firm responses to external demands for sustainable forest management. Policy Sciences, 33, pp. 1-30, 2000.

[13] Stern, P.C., Toward a Coherent Theory of Environmentally Significant Behaviour. Journal of Social Issues, 56(3), pp. 407-424, 2000. 
[14] Kagan, R.A., Thornton, D. \& Gunningham, N., Explaining Corporate Environmental Performance: How Does Regulation matter? Journal of Law and Society Association, 37(1), pp. 51-90, 2003.

[15] Cialdini, R.B., Crafting Normative Messages to Protect the Environment. Association for Psychological Science, 12, pp. 105-109, 2003.

[16] Kallgren, C.A., Reno, R.R. \& Cialdini, R.B., A focus Theory of Normative conduct: When Norms Do and Do not Affect Behaviour. Society for Personality and Social Psychology, 26(8), pp. 1002-1012, 2000.

[17] Bargh, J.A. \& Ferguson, M.J., Beyond Behaviourism: On the Automaticity of Higher Mental Processes. Psychological Bulletin, 126(6), pp. 925-945, 2000.

[18] Lachman, R., Nedd, A. \& Hinings, B., Analyzing Cross-national Management and Organisations. A Theoretical Framework. Management Science, 40(1), pp. 40-55, 1994.

[19] Cialdini, R.B., Reno, R.R. \& Kallgren, C.A., A Focus Theory of Normative Conduct: Recycling the concept of Norms to Reduce Littering in Public Places. Journal of Personality and Social Psychology, 58(6), pp. 1015-1026, 1990.

[20] Aarts, H. \& Dijksterhuis, Ap., Habits as Knowledge Structures: Automaticity in Goal Directed Behaviour. Journal of Personality and Social Psychology, 78(1), pp. 53-63, 2000.

[21] Dewhurst, H. \& Thomas, R., Encouraging Sustainable Business Practices in a Non-regulatory Environment: A Case Study of Small Tourism Firms in a UK National Park. Journal of sustainable tourism, 11(5), pp. 383-403, 2003.

[22] Nye, M. \& Hargreaves, T., Exploring the Social Dynamics of Proenvironmental Behaviour Changes: A Comparative Study of Intervention Processes at Home and Work. Journal of Industrial Ecology, 14(1), pp. 137-149, 2009.

[23] Aarts, H. \& Dijksterhuis, Ap., The Silence of the Library: Environment, Situational Norm, and Social Behaviour. Journal of Personality and Social Psychology. 84(1), pp. 18-28, 2003.

[24] Rothman, A.J., Towards a Theory -Based Analysis of Behavioural Maintenance. Health Psychology, 19(1), pp. 64-69, 2000.

[25] Baker, J.P. \& Ozaki, R., Pro-environmental products: marketing influence on consumer porches decision. Journal of Consumer Marketing, 25(5), pp. 281-293, 2008.

[26] Kollmuss, A. \& Agyeman, J., Mind the Gap: Why do people act environmentally and what are the barriers to pro-environmental behaviour? Environmental Education Research, 8(3), pp. 239-260, 2002. 